\title{
Meanings and Motives for Consumers' Sustainable Actions in the Food and Clothing Domains
}

\author{
Catalin M. Stancu *, Alice Grønhøj $\$ and Liisa Lähteenmäki \\ MAPP Centre, Department of Management, Aarhus University, Fuglesangs Allé 4, 8210 Aarhus V, Denmark; \\ alg@mgmt.au.dk (A.G.); liisal@mgmt.au.dk (L.L.) \\ * Correspondence: cast@mgmt.au.dk
}

Received: 29 September 2020; Accepted: 9 December 2020; Published: 12 December 2020

\begin{abstract}
The concept of sustainability has been widely discussed in the public arena by public entities and companies; however, consumers express inconsistency and confusion around the meaning of sustainability. This study aims to provide insights into consumers' associations with the concept of sustainability in general and within two behavioural domains that represent daily necessities (i.e., food and clothing), in addition to exploring the motivational drivers behind sustainable behaviours. A total of 23 semi-structured interviews were conducted with young consumers in Denmark to address this aim. Consumers perceived the concept of sustainability as complex and mainly related it to environmental aspects, whereas social and economic aspects were less emphasised. The interviewees used examples of sustainable behaviours, which cover the whole consumption-cycle, when interpreting sustainability. Consumers had various motivations to engage in sustainable behaviours and these varied by the stage in the consumption-cycle and domain. The interviewees displayed external motivation (e.g., save money, better taste), introjected motivation (e.g., impress others, public self-consciousness), internalised motivation (e.g., reflection of self) and even intrinsic motivation (e.g., pure interest) to engage in different types of sustainable food or clothing behaviours across the consumption-cycle. Different types of motivations drove the same behaviour, suggesting potential synergies or internal conflicts.
\end{abstract}

Keywords: sustainability understanding; motivation; sustainable behaviour; self-determination

\section{Introduction}

Consumers, as users of products, play a critical role in sustainability as they contribute to the pressure put on the planetary boundaries through their consumption [1-3]. Sustainability refers to fulfilling current needs without jeopardizing those of future generations [4] and supporting efforts to protect the environment [5].

Researchers, industry representatives and policymakers focus their attention and efforts on sustainability as a solution to the current environmental and social issues. Both the United Nations, at a global level, and the European Union at regional levels, have put forward a range of initiatives, actions and goals aimed at attaining sustainable development [6,7]. Likewise, industries respond to calls for sustainability by making efforts to integrate sustainability in their businesses and deliver sustainable products to consumers [8]. As a result, the business sector and public entities are increasingly using the concept of sustainability in their communication strategies.

In this context, it is important to assess how consumers understand sustainability and what they associate with this concept, as a potential lack of understanding may lead to diminished effectiveness of communication strategies and, further, to public alienation from sustainability issues. Consumers are increasingly concerned with sustainability; however, it is unclear how they make sense of the complexity of the sustainability concept [9]. Previous research identifies gaps in consumer 
understanding of sustainability $[10,11]$ as well as a need for further research on this issue-e.g., [12,13]. While sustainability is a concept of general interest amongst consumers, their choices may be influenced by several other issues such as healthiness, perceived quality, public self-consciousness or appearance and therefore a general concern for sustainability may not necessarily translate into sustainable action. There seem to be differences between people's conceptualisation of sustainability at the general or abstract level, compared to more concrete levels (e.g., product sustainability) and people transfer concepts across domains when making sense of sustainability at the domain level [14,15].

Two of the major industries associated with negative social and environmental impacts are the food and clothing domains [16-18]; however, both food and clothes are everyday products that represent unavoidable necessities for people. These domains are particularly interesting to study as food and clothes have different utilities for people, which can be reflected in the importance that consumers place on sustainability across these domains. Food is ingested and becomes part of the body, which makes healthiness and safety crucial, whereas clothes are a layer on the body, which is visible for others and thereby has social relevance. In this article, sustainable behaviour represents an action undertaken by consumers, which contributes towards fulfilling sustainable goals, regardless of whether its enactment was intended to serve that purpose or not.

Consumers' behavioural intentions are theoretically seen as the closest driver of behaviour [19] and represent an important antecedent of sustainable behaviours in food-e.g., [20] and in clothing e.g., [21]. However, moving beyond behavioural intention, further investigation into what motivates individuals to engage in sustainable behaviours is needed [22]. Some authors distinguish between altruistic and egoistic motivations-e.g., [23,24] as drivers of sustainable behaviour-whereas others have focused on values as motivational drivers of sustainable behaviours drawing on the norm activation model or value-belief norm [25-28]. In this study, we draw on self-determination theory [29] to explore the types of motivation and the degree to which they are self-determined across the two domains of interest.

The objective of this study is twofold. First, to gain a better understanding of meanings that consumers associate with the concept of sustainability with an emphasis on the food and clothing domains. Second, to explore motivational drivers of sustainable behaviours in the two domains specifically as these relate to the different stages of the consumption-cycle. This allows us to explore the similarities and differences in consumer perceptions and motivational drivers of sustainability in food and clothing. It also contributes to our understanding of how to promote sustainable behaviours in these domains whilst also highlighting different motivations for behaving sustainably within each domain depending on the specific consumption stage.

\section{Prior Literature and Theoretical Background}

\subsection{Sustainability Understanding}

Earlier studies suggested that people did not grasp the concept of sustainability [30]; however, consumers have become increasingly aware of sustainability and have started to demand products that account for sustainability [8]. Sustainability is a complex concept linked, by consumers, with environmental (e.g., green, environmentally friendly), social (e.g., workplace ethics, fair treatment) or economic (e.g., financial balance, economy) aspects [9,12,31,32]. Hanss and Böhm [12] found that the social and economic aspects were less emphasised in consumers' discourses, and although the multifaceted nature of sustainability was supported by Barone, Rodrigues [31], there was a variety of different dimensions associated with sustainability in consumers' minds. In addition to environmental, social or economic aspects, consumers' top-of-mind associations with sustainability included dimensions such as health and nutrition, productivity, nourishment or policy [31].

As was the case for sustainability in general, research by Grunert and colleagues [14] showed that consumers link sustainability mainly with environmental issues in food. This was further supported in the study by Peano and colleagues [33] where "preservation of natural resources" was most important 
for the definition of sustainability in consumers' views, followed by "decent working conditions" and "accessibility for everyone to healthy and safe food". Similarly, Gam and Banning [34] showed that consumers focused on environmental aspects such as use of organic or recycled materials and green production processes when defining sustainability in clothing. In addition to environmental considerations, aspects related to long product life were associated by young females with the sustainability concept in clothing [10]. Consumers transfer knowledge from the food domain when interpreting sustainability in clothing, implying that there can be similarities and differences between the domains in terms of the meanings associated with sustainability or the depth of understanding [15].

Some previous studies have focused on certain labelling elements aimed to communicate sustainability, mainly in the food domain. There is no single label communicating the overall sustainability of food or clothing products. Consumers had favourable expectations of foods labelled organic [35], local [36], eco-friendly [37], or fair-trade [38]. Even when consumer awareness of certain food labels (e.g., fair trade, rainforest alliance) was low, consumers could infer their meaning [14]. The design of the label is an important element that can affect consumer responses to labelled foods [39]. In clothing, consumers were willing to buy products labelled as "no sweat" [40] or "eco-friendly" [41].

Few studies have looked at consumer understanding of sustainability across several domains, as the vast majority have investigated sustainability either in general—e.g., [12]—or in a specific domain-e.g., [15]. Furthermore, prior studies have often considered only one specific facet of sustainability (e.g., pro-environmental behaviours) [42,43] or specific ways to communicate sustainability (e.g., labels) [44].

\subsection{Motivation for Sustainable Actions}

According to motivation theories, the core driver of behaviour is identity-based motivation [45]. Motivation refers to "the processes that cause people to behave as they do [and] occur when a need is aroused that the consumer wishes to satisfy" [46] (p. 91). Motives could be specific to a single behaviour or could be more generic such as norms or values as proposed by theories such as norm activation theory [47] or value theories-e.g., [48]. Such higher generic motives (e.g., morality) can drive several behaviours [49]; hence, in order to sustain and promote sustainable behaviours across domains, it is relevant to understand such motivational factors among consumers.

Self-determination Theory (SDT) proposes three main types of motivation-namely intrinsic, extrinsic motivation and amotivation (i.e., lack of motivation) [50], which may be linked with various sustainable behaviours. Intrinsic motivation is characterised by personal interests that are naturally enjoyable or satisfying while extrinsic motivation refers to performing an activity due to adoption of external (to self) factors coming from social and cultural environments. Extrinsic motivation is further divided into four types of motivation that vary in the degree to which the external contingencies have been internalised to the self. An overview of the types of motivation is depicted in Figure 1 below.

A behaviour is motivated by external motivation when the action is performed either in order to avoid being punished or to gain a reward (e.g., bringing a plastic bottle to the collection system to gain a financial incentive). Introjected motivation refers to a behaviour driven by self-esteem-based contingencies, either positive, such as feeling proud or worthwhile, or negative, such as feeling guilt, shame or self-deprecation, or looking for others' approval (e.g., buying sustainable products in order to gain the appreciation of others). Identified and integrated motivations can be seen as internalised extrinsic motivation. In the case of the former, people recognise the value and importance of a behaviour and accept it as their own meaningful action/regulation. While, for the latter, the motivation is in line with one's core sense of identity, resulting in self-determined motivation. Behaviours are driven by such motivation when regulations have been internalised and brought into harmony with existing values, goals and needs that are rooted in the self-concept $[29,50]$.

The SDT framework was deemed suitable for the purpose of this study to understand how consumers express their motivations in relation to sustainable behaviours. This research focuses on the various motivations driving sustainable behaviours, regardless of whether these motivations refer 
to sustainability reasons (e.g., completing an activity to protect the environment) or other reasons that are not sustainable as such (e.g., social norms, egoistic motivations). Using this theoretical lens makes it possible to identify the different types of motivations that people have, as well as the external factors that influence consumer behaviour. The theoretical grouping of motivations has implications for the expected effects of these motivational types on behaviour. More specifically, motivations that are more internalised to the "self" drive more frequent sustainable behaviours such as recycling or conservation behaviours [51,52] and relate positively to engaging in several pro-environmental behaviours, rather than just one [53]. Therefore, using SDT as the theoretical lens to understand and categorise consumer motivations is relevant when exploring sustainable behaviours and their drivers. As the theory takes into account external contingencies, it sheds light not only on the motivations that are related to sustainability, but also on other reasons that people may have to act sustainably. Moreover, it helps to make inferences about how important different motives are for promotion of sustainable behaviours.

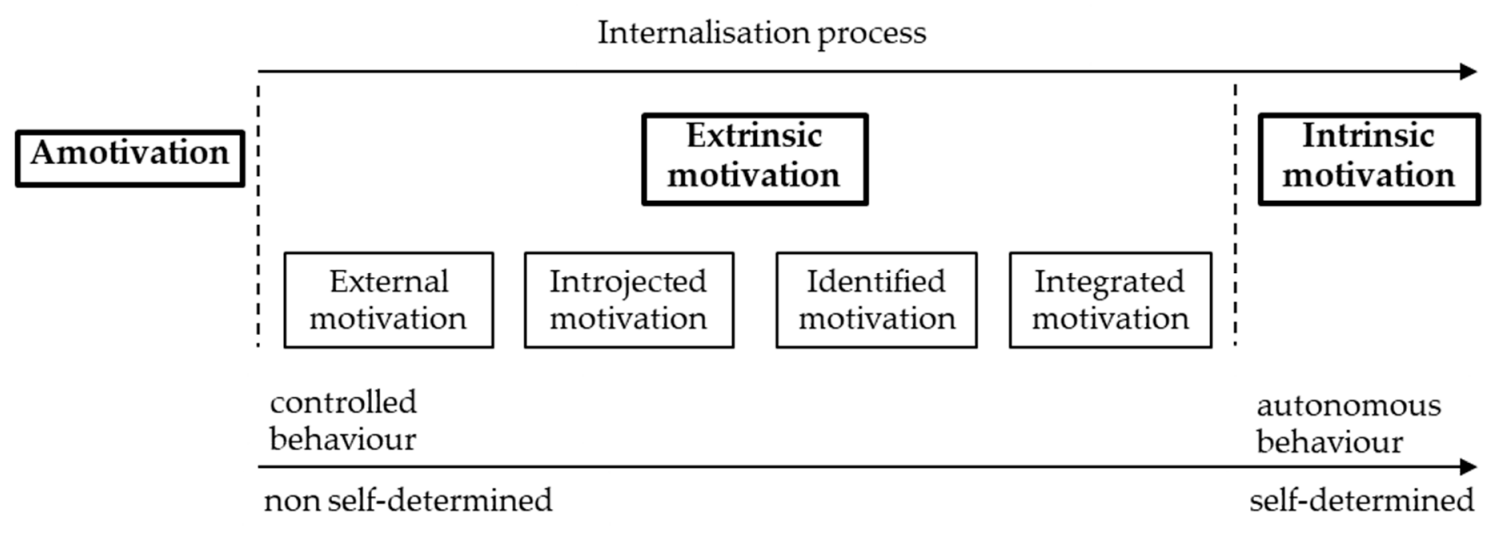

Figure 1. Motivations placed on the self-determination continuum proposed by Self-determination Theory (SDT) [50].

\section{Materials and Methods}

This research employs a qualitative approach as this methodology is recommended to study complex, unclear or even internally conflicting constructs such as sustainability and its underlying drivers [54]. Semi-structured interviews were conducted to capture interviewees' reflections on the sustainability concept and drivers of sustainable behaviours in the food and clothing domain while allowing them to depart from the predetermined interview guide.

\subsection{Interviewees and Recruitment}

The empirical data consist of twenty-three semi-structured interviews with young consumers aged between 18 and 38 years old. Understanding the perceptions and behaviour of young consumers is highly relevant as they are considered one of the "most powerful consumer group in the global market place" [55] (p. 114) and represent the future. Moreover, young individuals are politically and socially active, therefore are an influential group in today's society. There is mixed evidence as to whether young consumers are engaged in sustainable behaviours [56,57], although some show that young consumers are highly aware and concerned about environmental issues [58].

The participants were recruited via posters in various locations across a large city in Denmark and online through a forum or the university cognition lab panel. In line with the objectives of this study, participants were screened via an online survey to have at least a score of 20 on a scale from 0 (not at all) to 100 (highly) on their "interest in and perceived importance of sustainability" in relation to food and clothing.

Twenty-three individuals were interviewed face-to-face by the first author. The length of the interviews (up to $90 \mathrm{~min}$ ) facilitated consumers' thorough reflections on meanings and practices related 
to sustainability. The interviews were audio-recorded upon receiving consent from the participants. Data collection stopped when new interviews did not bring new insights for the purpose of the study. As this study follows a homogenous sampling strategy, this phenomenon is likely to emerge [59]. The interviewees' age ranged between 20 and 38 years old and most of them were females $(65 \%)$. All participants gave their informed consent for inclusion before they took part in the study. The study was conducted in accordance with the Declaration of Helsinki, and the protocol was approved by the Human Subjects Committee of the university's cognition lab (project ID 0213/2018).

\subsection{Interview Guide}

The interviews followed an interview guide (Appendix A) that was divided into four sections: (1) general understanding of sustainability, (2) general sustainable behaviours, (3) sustainability concepts and own experiences within the clothes domain and (4) sustainability concepts and own experiences within the food domain. As consumers seem to have a more complex understanding of sustainability in food compared to clothing [15], the discussion first covered the apparel domain to avoid carry-over effects of meanings and motivations from the food domain.

Several criteria have been followed to ensure the trustworthiness and quality of this qualitative research as recommended by Shenton [60]. The questions included in the interview guide were derived in part from previous literature that elicited motivations relevant to sustainable consumer choices [12,61]. Moreover, the interview guide was pretested in order to eliminate potential lack of clarity.

\subsection{Data Analysis}

The data analyses were performed using NVivo12 software. To enhance trustworthiness, quotes from the interviews are presented to support interpretation of the data. All interviews were transcribed ad verbatim in preparation for the data analyses. Thematic analysis, which has been previously used in studies related to sustainable behaviours [62,63], was chosen as an appropriate method of analysis as it facilitates finding common themes across interviewees' discourses.

The transcript data were coded using a blended coding scheme, namely using both inductive and deductive approaches to derive codes [64]. In order to address the first objective of this study regarding meanings associated with sustainability, an inductive approach was used. In the first phase, the initial coding method was employed to break down the text for further interpretation and further coding cycles as recommended by Saldana [65]. This is an exploratory procedure where these codes are rooted in elements or segments of consumers' associations with sustainability or motivations that can be assessed in a meaningful way. This was followed by a second cycle of coding where the data were examined for thematic patterns, namely by collapsing initial codes together to form the overarching codes. For example, specific behaviours, used by interviewees to describe the meaning of sustainability, such as buying organic products, buying second-hand items, purchasing cradle-to-cradle or buying recyclable products were collapsed under the code "purchase behaviours".

In order to address the second objective of the paper, a deductive coding approach was applied. This represents a narrower approach to coding that allowed us to focus on theoretically relevant constructs-in this case, types of motivation that differ in their level of self-determination. The initial level of coding remained exploratory to some extent. However, following this approach, the level of complexity and variance of second-cycle codes is reduced when comparing data to existing theoretical concepts. 


\section{Results}

\subsection{Consumer Associations with the Concept of Sustainability in General}

In order to gain an understanding of the meanings that consumers attach to the concept of sustainability, the first section in the interview explored the top-of-mind associations with this concept, including the perceived importance of sustainability and sustainable products.

Interviewees were aware of sustainability to some extent and considered it important. Sustainability was associated in consumers' minds with several domains among which the most mentioned were food (e.g., organic production), apparel (e.g., worker conditions), energy (e.g., green or renewable energy, limiting energy use), transportation (e.g., use public transport), politics (e.g., supporting parties that have sustainability on their public agenda) or education (e.g., teaching one's children about sustainability). Overall, food appeared to be the easiest area to relate to sustainability, with an emphasis on production and organic products.

Overall, seven overarching themes were apparent in consumers' discourses in relation to their associations with the concept of sustainability in general; namely, environment, social, economic, temporal, personal, technology and behaviours. An overview of the themes and their constituent codes, as well as examples of interviewees' quotes for each of the identified themes, can be found in Appendix B.

The top-of-mind associations with the sustainability concept mostly covered references to the environmental dimension. The interviewees either referred broadly to the environment (code EN2) or emphasised environmental protection (code EN3), overexploitation or preservation of resources (code EN1) or debate on the production processes of products (EN4) in their attempts to make sense of the sustainability concept. Moreover, limiting one's carbon footprint (code EN5) and having a circular economy (code EN6) based on recycling and reusing products was discussed as part of the environmental dimension of sustainability. The environmental dimension of sustainability represented "the foundation for the other parts of sustainability", as stated by one participant.

In addition to the environmental theme, participants mentioned elements that pertain to the social dimension of sustainability, such as human rights (code S1), workers' wellbeing (code S2), avoiding products involving child labour (code S3) and political responsibility (code S4). The first three aspects can be linked to ethical considerations regarding human labour. Few responses showed a broader perspective of sustainability that included support for political parties or initiatives that are in accordance with sustainability principles (see Appendix B).

In addition to the environmental and social perspectives, the interviewees identified economic sustainability as one of the three concepts that fit under the sustainability umbrella (code E1). Economic sustainability implies setting a limit for resource exploitation so that it does not exceed Earth's available bio-capacity These concerns further fed into the temporal theme associated with sustainability-namely, that a long-term view is inherent to the concept of sustainability and, in order to be sustainable, products need to be long-lasting. Technology was highlighted as important in supporting sustainable behaviours such as waste reduction, car sharing or limiting energy consumption (e.g., mobile apps, efficient household appliances, solar panels).

There was some scepticism towards sustainability, with some individuals considering it as a current trend, a buzzword or associated with greenwashing. A third of the respondents found the concept of sustainability to be rather broad and overwhelming. In their attempts to describe their understanding of sustainability, a majority of interviewees used examples of sustainable behaviours. These can be categorised as restrictive or limiting behaviours (e.g., limiting water, energy, paper, waste, plastic use or meat consumption), purchasing behaviours (e.g., buying organic, local, or second-hand products), using in order to prolong the life of products (e.g., reusing old products) and disposal behaviours (see Appendix B). 


\subsection{Consumer Associations with the Concept of Sustainability in Food and Clothing}

Sustainability associations were elicited for each domain by asking respondents what makes clothes/food sustainable and to reflect on the lifecycle of products (Table 1). This contributes to previous literature by allowing a comparison between the food and clothing domains in terms of the meanings associated with sustainability.

Table 1. Meanings of sustainability in clothing and food.

\begin{tabular}{|c|c|c|c|c|}
\hline $\begin{array}{l}\text { Meaning } \\
\text { Themes }\end{array}$ & Clothing & Frequency * & Food & Frequency * \\
\hline \multirow{7}{*}{ Production } & material type & 17 & resources & 6 \\
\hline & environmental impact & 13 & environmental impact & 9 \\
\hline & production process & 21 & production process & 11 \\
\hline & workers' wellbeing & 17 & organic & 12 \\
\hline & & & animal welfare & 8 \\
\hline & & & workers' wellbeing & 4 \\
\hline & & & local & 11 \\
\hline \multirow{4}{*}{ Use } & repurposing & 3 & use leftovers & 7 \\
\hline & long-lasting & 18 & & \\
\hline & second-hand & 10 & & \\
\hline & prolonging life of clothes & 10 & & \\
\hline \multirow{3}{*}{ Disposal } & donating & 12 & reduce waste & 17 \\
\hline & $\begin{array}{l}\text { store's recycling } \\
\text { program }\end{array}$ & 3 & & \\
\hline & $\begin{array}{c}\text { waste of } \\
\text { clothes/overproduction }\end{array}$ & 6 & & \\
\hline Transport & carbon footprint & 10 & carbon footprint & 11 \\
\hline \multirow{4}{*}{ Behaviour } & avoid plastic wraps & 3 & avoid plastic wraps & 5 \\
\hline & $\begin{array}{l}\text { labelled as sustainable } \\
\text { (as a guide) }\end{array}$ & 3 & grow own food & 2 \\
\hline & limit consumption & 3 & limit meat & 6 \\
\hline & & & seasonality & 2 \\
\hline \multirow{2}{*}{ Other } & fuzzy term & 2 & taking care of own health & 9 \\
\hline & search for information & 4 & & \\
\hline
\end{tabular}

In the food domain, consumers' discourses involved associations related to the stages in the product lifecycle namely production, use and disposal, with the production stage being the most salient. Similar to sustainability in general, consumers emphasised the environmental impact of food production especially with regard to the effects of chemicals and fertilisers on flora and fauna (e.g., "we don't want to do too much damage to the Earth ... it will have consequences in many ways: weather-wise, species that go extinct"). Some interviewees see animal welfare as part of sustainability; however, they did not argue why (e.g., "animals have a good life with access to outdoor areas", "animal care, that the animals have a nice way of life before becoming a meal"). Sustainability may be regarded as an umbrella term that includes any concept related to protection or preservation.

Respondents closely linked sustainability in food with organic and local produce yet some were conflicted about which of the two is more sustainable. Transportation of products negatively affects the environment through carbon dioxide emissions supporting the sustainability of local produce (e.g., "the flying in of products is more harmful to the environment than actually buying the products"; "if you buy local foods then the transport isn't necessary, so less carbon dioxide"). On the other hand, another interviewee explained a preference for organic versus local—“the Danish apple or the Italian organic apple ... still haven't figured out what I think is the most correct thing to buy. But then I would buy the Italian organic apple because I would be concerned about the pesticides in the Danish non-organic apple". The lack of chemicals in 
organic produce is further associated with health benefits by many consumers (e.g., "if you don't eat organic then there might be something in the food that shouldn't be there that can make you sick").

In addition, most of the interviewees associated sustainability with reducing food waste in the supply chain (e.g., "it's important to actually use the food that has been produced instead of tossing it away"; "supermarkets should not buy more than they can sell and if so, donate them to people"). Only a few interviewees linked sustainability in food with social aspects such as farmers' fair pay.

Similar to the food domain, when talking about clothing, respondents frequently referred to the production of clothes. Avoidance of chemicals, careful use of resources and use of fabrics that are sustainable were identified as the main associations with sustainability. Aspects such as avoidance of pesticides when growing cotton, chemicals, bleach or artificial dyes, which further contaminates the water, were mentioned amongst criteria for sustainable clothing (e.g., "consider what kind of colour it is dyed with, because of course there are chemical and natural colours and then I prefer natural colours"). Sustainability refers to careful use of resources such as water (e.g., "for example, the way cotton is produced entails a lot of water consumption") or green energy (e.g., "How do factories run? Do they run sustainably, do they run on clean energy?"). Similar to the conflict between local and organic food in terms of which is more sustainable, interviewees were conflicted concerning the sustainability of various types of material used for creating clothes. Some considered organic cotton as a sustainable alternative to conventional cotton. On the other hand, others thought that sustainable clothes are made of bamboo or lyocell, as these are less water demanding, or from reusing old fabrics except plastics (e.g., "reuse some of the materials from other items instead of just burning them"). The type of material was important for interviewees when describing what sustainability is; however, there was no general consensus over what a sustainable fabric is.

Almost all interviewees referred to the social aspects of sustainability in their discourses about production of sustainable garments. They seemed to be more aware about social sustainability in the clothing domain compared to the food domain. The interviewees included aspects such as workers' wellbeing, no child exploitation, working conditions or fair pay as part of the sustainability concept in clothing (e.g., "you have workers that get a fair pay and an ok working environment and they don't sit crammed in a factory working all day long"). The majority of our participants underlined the fact that clothes are usually made in far-away countries and that transportation contributes negatively to the environment.

In clothing, compared to food, the use stage in the product-cycle seems more closely linked to sustainability in consumers' minds. The majority of our participants saw sustainability as the opposite of the fast fashion concept. Sustainable clothes were seen as being of good quality and as long-lasting. In consequence, this means that people purchase fewer clothes, which eventually decreases production of new clothes and leads to less pollution (e.g., "we talk too little about clothing waste because we have huge production"; "I think the longer the life the product has when it gets home, the more sustainable it is"). In interviewees' discourses, using clothes for longer was closely linked to using second-hand clothes or prolonging the life of a garment by fixing, mending or avoiding washing it too frequently. At the end of the clothes' lifecycle, consumers talk about donating their clothes to thrift shops or delivering them back to the store for recycling purposes, as throwing clothes away was perceived as wasteful. In a few instances, respondents relied on their knowledge from food to talk about sustainability in clothing (e.g., "It's like food waste for me: if others can benefit from it, why waste by just throwing it out?", "clothing is the same as with food you can get local clothing that you know is made in a more sustainable way").

\subsection{Behaviours Linked to Sustainability in Food and Apparel}

In order to address the second objective of this study, namely what are the motivations behind acting sustainably, interviewees were asked to elaborate on their sustainable behaviours in the two domains (i.e., apparel and food).

A variety of sustainable behaviours that people engage in when it comes to clothing and food were elicited (Table 2). These behaviours spread across different stages of the consumption-cycle-namely purchasing, limiting, using and disposal. Consumers viewed sustainability as a concept that affects 
not only their product choices when buying foods and clothes, but also using and disposing of these products. Furthermore, some consumers seemed to be conscious about the extent of their consumption and actively engaged in activities that reduce their consumption of food or clothes. Certain categories of behaviour were more evident in one domain compared to the other. People engaged in a larger variety of sustainable purchase behaviours in the food domain compared to clothing. On the other hand, more sustainable behaviours in the use or disposal categories were more evident in relation to clothing food.

Table 2. Examples of own behaviours linked to sustainability.

\begin{tabular}{|c|c|c|}
\hline Behaviour Category & Apparel Domain & Food Domain \\
\hline Purchasing & $\begin{array}{c}\text { second-hand } \\
\text { labelled clothes } \\
\text { long-lasting materials }\end{array}$ & $\begin{array}{c}\text { box subscription } \\
\text { single pieces of fruits } \\
\text { ecological/organic } \\
\text { close to expiration (suboptimal foods) } \\
\text { labelled products } \\
\text { local products } \\
\text { what is in season }\end{array}$ \\
\hline Restrictive & $\begin{array}{c}\text { limit purchases of clothes } \\
\text { limit consumption of new clothes } \\
\text { limit wash } \\
\text { no softener } \\
\text { eco softeners and soaps }\end{array}$ & $\begin{array}{c}\text { avoid food waste (limit amount of food } \\
\text { bought) } \\
\text { limit meat consumption } \\
\text { hold back from impulse buying } \\
\text { avoid products made of endangered species } \\
\text { avoid palm oil } \\
\text { avoid excess/unnecessary plastic packaging }\end{array}$ \\
\hline Using & $\begin{array}{l}\text { repair clothes } \\
\text { repurpose clothes } \\
\text { share/swap clothes } \\
\text { use clothes longer }\end{array}$ & use leftovers \\
\hline Disposal & $\begin{array}{l}\text { donate clothes } \\
\text { give clothes to recycling } \\
\text { programme at store } \\
\text { sell clothes }\end{array}$ & $\begin{array}{l}\text { recycling } \\
\text { composting }\end{array}$ \\
\hline Other & $\begin{array}{l}\text { research before purchase } \\
\text { make own clothes }\end{array}$ & $\begin{array}{c}\text { compare products before purchasing } \\
\text { research before purchase } \\
\text { bring own bag } \\
\text { grow own food } \\
\text { take care of own health } \\
\text { make shopping list } \\
\text { learn from mistakes (food waste) } \\
\text { have a meal plan }\end{array}$ \\
\hline
\end{tabular}

\subsection{Motivations behind Sustainable Actions in the Apparel and Food Domains}

People had various motives for engaging in sustainable behaviours across the consumption-cycle and domains. A closer look at these drivers can enrich our understanding of sustainable behaviours and ways to promote them. In the following, the theoretical lens of self-determination theory [29] was used to categorise the motivations elicited from interviewees for engaging in behaviours that they perceive as sustainable. The elicited motivations varied by stage in the consumption-cycle and domain. Figure 2 below provides a visual overview of the main motivations by domain and stage in the consumption-cycle. 


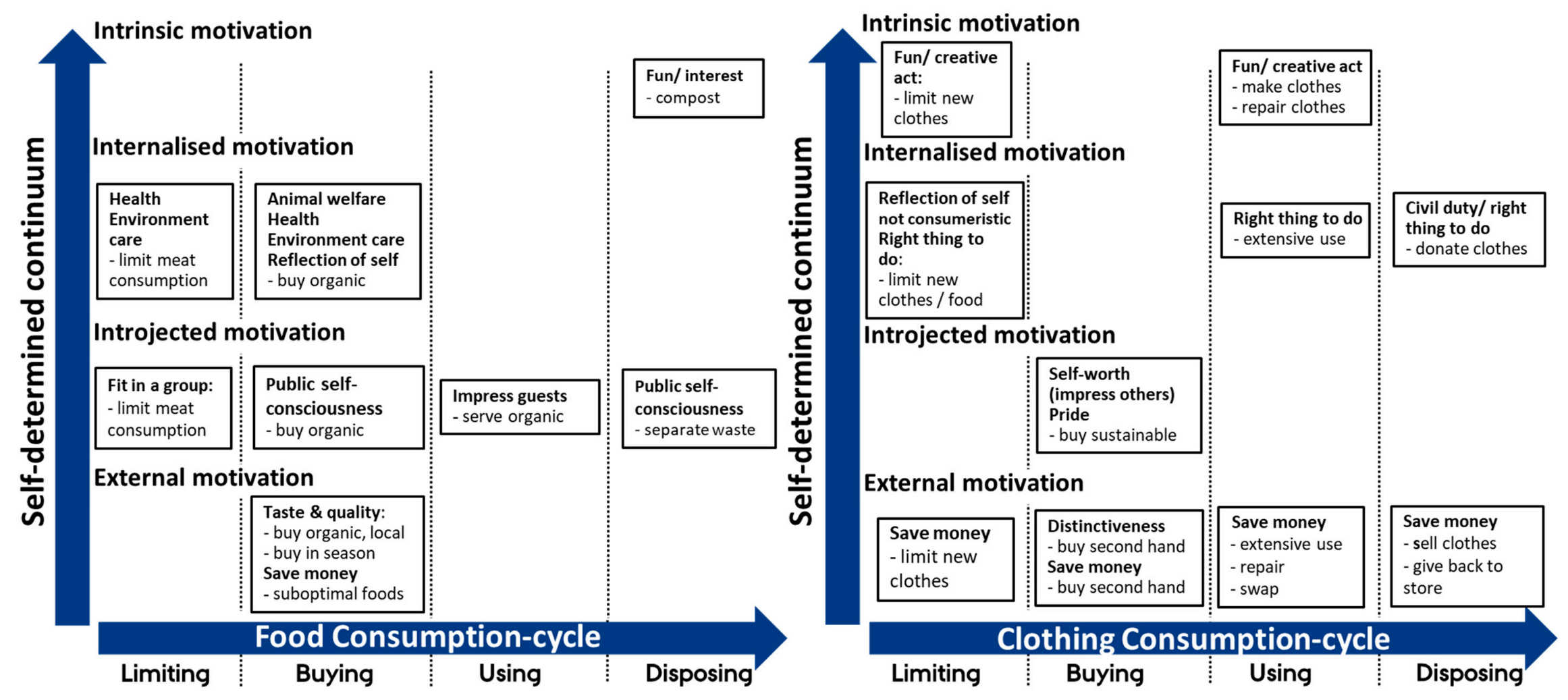

Figure 2. Motivations that drive sustainable behaviours across the consumption-cycle in food and clothing. Note: External motivation-refers to taking part in an activity to avoid being punished or in order to receive a reward; introjected motivation refers to performing an activity for self-worth purposes or in order to avoid feeling guilty; internalised motivation refers to doing something that defines one as a person as that activity is in line with one's values; intrinsic motivation refers to engaging in a behaviour out of personal interests, curiosity or because of pure enjoyment. 


\subsubsection{Motivations that Drive Sustainable Behaviours in the Food Domain}

In food, interviewees mentioned several motives for engaging in behaviours that reflected the consumption-cycle (e.g., limiting meat consumption, buying sustainable alternatives, disposing of food).

In the limiting stage of the consumption-cycle interviewees engaged in restrictive behaviours (e.g., limiting meat consumption) for various reasons. Limiting meat consumption was sometimes driven by the desire to fit in better within a social group (e.g., "I' $m$ trying to eat less meat but also because I have so many vegan friends so if I have them coming over I have to have less meat"), which can be seen as introjected motivation. This type of motivation was mostly apparent in food, whereas other times people talked about motives that can be seen as internalised motivation (identified or integrated). Limiting meat consumption was motivated by environmental concern (e.g., "But also thinking about having a day or two a week with not buying meat just because of the greenhouse impact it could have"), health reasons (e.g., "from the research and the knowledge I have and what I feel that is best for me and for my body and what is more sustainable, is definitely to limit the amount of meat and processed foods") or the perception that this is the moral thing to do ("Not eating meat I think it's or eating less meat I think is the moral thing to do"). In a similar vein, limiting the amount of food wasted was linked to a foundational value and was perceived as the "right thing to do".

Motivations behind behaviours in the buying stage of the consumption-cycle (e.g., buying organic or suboptimal food) varied from external to internalised motivation. Suboptimal food products (i.e., products that are discounted because they are close to expiration) were bought because they were cheaper, showing external motivation. Perceived good taste or superior quality in organic food products can be interpreted as an external motivation as it provides a personal gain (e.g., "organic food for example, I have an idea that is something of quality; that I get something with higher quality than the other things.") that is necessary in order to repeat the behaviour. However, if organic products fail to deliver on taste then the conventional option would be preferred in the future. Taste was repeatedly mentioned as a driver of purchasing according to season, local or organic food products. Local products were deemed tastier as "the imported ones have been harvested too early, transported across the globe and don't taste as good", whereas products in season were viewed as "the best version" taste-wise. Taste is, therefore, considered to fit under the external type of motivation in sustainable behaviour as products are purchased in order to obtain hedonic pleasure from consuming them and people would not buy those products if this reward is not perceived.

Buying organic or other sustainable alternatives were also motivated by self-esteem contingencies manifested as public self-consciousness or as a need for the others' approval, which fit under introjected motivation. In this respect, food purchases were sometimes seen as a tool to create a good image in front of others or try to avoid being judged (e.g., "I am someone who is very tempted to buy things that looks good in a package and that is mostly organic food. Maybe I think a lot about what people would think of me when I get to the cash register (... )").

Buying sustainable products could also be in line with interviewees' values or an important part of who they are as a person showing internalised (identified or integrated) motivation. This type of motivation was mostly apparent in the food domain. Purchasing behaviours, such as buying organic products, were driven by internalised motivation based on a set of values, such as respecting animal wellbeing and organic certifications were perceived to ensure better life conditions for animals. It was difficult for interviewees to assess the importance of the motivation driving the purchase of organic fruits and vegetables when considering health and environment (e.g., "Both for myself and my health and also for the soil and farmers. If [pesticide] is sprayed onto the vegetables then it would also go down into the soil and the water and pollute."; "I mean my own health probably comes after protecting the environment but I cannot say that 100\%"). These quotes demonstrate that some interviewees identified with the value of consuming organic produce-namely, avoiding harmful substances that might negatively influence their health. This is similar to identifying with the importance of exercising for one's own health, which is established in the SDT literature as an example of internalised regulation [66]. 
The use and disposal stages in the consumption-cycle were not highly emphasised in the food domain. Some behaviours in these stages were driven by introjected motivation as well. One's own image in front of others motivates people to try and adapt their behaviour in certain social contexts such as at work, when having friends over, or simply when accompanied by others (e.g., "I guess I also feel like an example to others. Kind of boosts my ego. Also, if I'm having guests I like them to have something that is nice"). Organic products, especially, were seen as the best product type and a must when having guests over.

Some disposal behaviours driven by introjected motivation were related to waste separation of food products packaging (e.g., “Then people can't judge my choices because they are the right ones according to society"; "I want to seem like a good person so I would not put a glass bottle in my waste (... ) if I was with someone and they would be disappointed, I would not do it").

Behaviour at the disposal stage could also be performed out of intrinsic motivation, when the behaviour brought joy or was driven by genuine curiosity, such as composting food waste to an interviewee (e.g., "I have this compostable kind of thing so it's very interesting to follow the process (...) putting it out into the garden and see plants growing out of that").

\subsubsection{Motivations that Drive Sustainable Behaviours in the Clothing Domain}

Similar to the food domain, several motivations drove interviewees' sustainable behaviours across the consumption-cycle, even though there were some differences as well. Behaviours in the limiting stage of the consumption-cycle, such as limiting the purchase of new clothes, were driven for some financial aspects showing external motivation. This was mainly the case in the clothing domain (e.g., "I don't have the money to just go out and buy a new jacket").

On the other hand, being mindful about restricting the amount of clothes purchased was sometimes linked with sustainability. This behaviour is not motivated by external contingencies (e.g., save money), but it comes as a reflection of the self (e.g., "I just think I would feel very consumerist if I had 20 blouses or 10 of pairs of shoes. I wouldn't be comfortable with that") and out of awareness of the consequences linked with unnecessary purchases (e.g., "I have an idea what the consequences are, I think I'm aware of only buying things that I need"), showing internalised motivation.

In some cases, engaging in limiting or any other kind of sustainable behaviour was due to enjoyment only-namely, intrinsic motivation. Some general restrictive behaviours (one avoids purchasing new garments by repairing old ones) were an expression of a lifestyle choice and of personal creativity (e.g., "I think the lifestyle which is connected to being creative and choosing your own clothes and not buying into (...) what is served in the clothing shops but finding your way around these things in my head it's related to sustainability").

When looking at the clothing domain compared to the food domain, some overall similarities and differences in drivers of limiting behaviours emerged. External motivation was more apparent in relation to clothing, whereas introjected motivation was more apparent in food. Some people engaged in limiting behaviours in both domains because they saw the value for the environment in doing so, or because they thought it was the "right thing to do". Having fun while limiting the purchase of new clothes due to being able to use their creativity in repairing clothes or making their own clothes was rarely elicited. In clothing, limiting behaviours were driven by external motives but also by highly internalised types of motivations, whereas in food these behaviours were driven mainly by social pressure or due to those actions being in line with interviewees' personal values.

Motivation behind behaviours in the buying stage in the consumption-cycle represented mainly external or introjected motivations. Sustainable purchasing behaviours such as buying second-hand clothes were motivated by external motivations involving financial gains (e.g., saving money) or other personal gains (e.g., distinctiveness) (e.g., "Because then I can get something that other people don't have and I can be cool and I can save money", "getting new things cheaply and different to what everybody else is buying in the store"). 
Self-esteem contingencies, which fit under introjected motivation, drove some purchasing behaviours in clothing. As one interviewee emphasised, it would be important to have a distinguishable symbol on garments that can be seen by others, thereby making the purchase worthwhile (e.g., "it would be because I would want them to see that it had this mark that indicated the sustainability of it and then yeah people would think that it was a good choice (... ) that would motivate me to buy more sustainable clothing"). However, if the symbol was not distinguishable, then the efforts of having chosen clothes carrying the symbol would not be worthwhile (e.g., "nobody would even know it. So I wouldn't get much credit for doing that").

There were many similarities between food and clothing in terms of drivers of sustainable purchasing behaviours. However, clothing purchases seem to be driven by less internalised types of motivation, whereas in food some consumers engage in purchasing sustainable options because they see the value of doing so for the environment or animal welfare or as a reflection of their self.

The use stage in the consumption-cycle was more emphasised in clothing (e.g., use clothes for longer, repair clothes) compared to food (e.g., serve food to guests). Some interviewees were motivated by financial gains to use their garments for longer periods of time, fix or swap their clothes (e.g., "I can keep using it instead of throwing it out and buying a new one but that is also an economical issue. I don't have the money to just go out and buy a new jacket, I might as well just fix the one I have so it's sustainable but also economical), showing external motivation.

Extensive use of clothes was viewed as common sense to limit "clothing waste" by not throwing out something that can still be used, which can be seen as internalised motivation (identified or integrated). Furthermore, in some cases, consumers found ways to use their clothes longer by, for example, repairing them, as an expression of personal creativity that was in line with their lifestyle. This can be seen as intrinsic motivation as for those interviewees it was fun to carry out such behaviours.

In the use stage of the consumption-cycle, there was a higher emphasis on the clothing domain. People use their clothes for longer due to external motives (e.g., save money), because it is the "right thing to do" or because they want to express their creativity in doing so. In the food domain, there was not much emphasis on the use stage except that sustainable food can be used sometimes to impress others.

At the end of the garments' lifecycle, the disposal stage, respondents shared that they donate unwanted clothes, sell them or bring them back to the store as part of a recycling program. The latter two are motivated, respectively, by financial benefits in the form of money or discounts for new in-store purchases showing external motivation. Disposal related behaviours such as donating clothes could also be in line with interviewee's values and an important part of who they are as a person, showing internalised (identified or integrated) motivation. Interviewees engaged in donating clothes because they perceived them as important (e.g., contributing to others' happiness, protecting the environment) or as a civic duty and something normal to do. Some interviewees donate clothes directly to second-hand stores or via civic society organizations such as Red Cross because they see it as the "right thing to do", while others view it as common sense to limit "clothing waste" by not throwing out something that can still be used (e.g., "it is so easy to help somebody just by taking your clothes to the second-hand store and potentially helping somebody"). Donating clothes is sometimes associated with positive feelings about oneself, an accomplishment which contributes to a good state of mind and good conscience (e.g., "if I donate clothes I feel good about myself the same way I feel good about myself if I donate blood"). Recycling is motivated by environmental care; however, it is also regarded as something "that you have to do" as it became an easier activity to carry out due to improved infrastructure (i.e., many donation containers around the city).

Various types of motives drove disposal behaviours in food and clothing. In clothing, disposal behaviours that can be seen as sustainable (e.g., donating old clothes) were driven by external motivation or because people saw these as the "right thing to do". In food, the motivation, for disposal that can be seen as sustainable was mainly about one's image in front of others or was an interesting behaviour that fed people's curiosity. 
When comparing the two domains, the elicited motivations varied to some extent by the domain and stage in the consumption-cycle. External motivation was more apparent in clothing where it drove behaviours across the consumption-cycle, compared to food where it was linked mainly to purchase. The reverse was true for introjected motivation, which was more apparent in food than clothing. Behaviours in several stages of the consumption-cycle were driven by internalising the value of the behaviour in food and clothing. In food, the steps in the beginning of the consumption-cycle were linked with such motivation, whereas in clothing the end of the cycle was also driven by such values. Intrinsic motivation was less emphasised in both domains but linked more with clothes.

\subsubsection{Amotivation in Food and Clothing}

Amotivation (i.e., lack of motivation) was more apparent in the apparel domain compared to food. Lack of availability (e.g., “the reason why I don't think about it (i.e., sustainability) when I buy clothes is that it's not that much into the clothing market") or guidance regarding sustainable apparel alternatives (e.g., "I lack some information about which materials are generally better for the environment", "in the purchase situation then it's ... well it is too big of a problem so I guess ... then I just give up") contributed to people's amotivation, especially in relation to buying clothes. Moreover, compared to food, people perceived that there is less focus on clothing sustainability issues in public or private social debates. Even though interviewees were screened to have at least some interest in sustainability in food and clothing, the reasons described so far may impede the satisfaction of people's needs for autonomy, competency and relatedness in relation to buying clothes, which in turn facilitates amotivation as proposed by SDT.

\section{Discussion}

The present study aimed to explore how consumers understand the concept of sustainability with emphasis on the food and clothing domains as well as the motivations that drive sustainable actions in the two domains.

Besides corroborating previous literature where environmental aspects were prevalent in consumers' associations with the concept of sustainability in general $[12,31,67]$ or in a specific domain—e.g., clothing $[10,12,68]$ — the present study extends this literature by exploring the similarities and differences in the associations that people make with sustainability across two specific domains-food and clothing. Whereas environmental aspects were the closest associations with sustainability in consumers' minds in both domains, social aspects (e.g., worker wellbeing) were more closely linked with sustainability in clothing rather than food. This adds to insights of Hill and Lee [10], where sustainability in clothing was linked mainly to ecological issues. Heavily covered stories in the media related to workers' wellbeing in the clothing industry [69] might have triggered reflection from consumers and explain this difference between food and clothing. Unlike previous literature suggesting that consumers transfer some of their knowledge from the food domain when trying to interpret sustainability in the apparel domain $[15,70]$, in the present study interviewees rarely transferred meanings from food to clothing.

Consumers used examples of sustainable behaviours to express their views of sustainability, which can be seen as an attempt to decrease the abstractness and complexity of this concept. In addition, when explicitly asked about the sustainable behaviours that they engage in around food and clothing, the elicited behaviours in each domain reflected the entire consumption-cycle of a product [71]. Compared to clothing where the emphasis was placed on the use and disposal stages, in food the buying stage was more apparent. The low emphasis on buying in clothing may be due to the old-fashioned image that consumers hold of sustainable clothing [72], their mistrust in companies or lack of explicit information to support their choices [73]. In food, seeking sustainable alternatives is established and there is mainstream access to such options. Moreover, buying sustainable food is perceived as having various benefits, some of which relate to consumers' self-interests such as contribution to health $[70,74]$. On the other hand, sustainable options in clothing are less accessible on 
the market and they contribute less to direct benefits for the consumers [70,75]. Furthermore, both food and clothing are necessities; however, food is bought frequently and used in short cycles whereas clothing is bought less frequently, but used for longer. Clothing products are higher investment compared to food [76]. These differences in the nature of the two domains may further explain the focus on buying in food versus use in clothing.

In terms of motivation, besides showing that the types of motivation proposed by SDT can be used to interpret the motives elicited from consumers [50], this study contributes to the previous literature by providing insights into the complexity of motivations behind behaviours across the consumption-cycle in food and clothing. People sometimes engage in sustainable behaviours for the sake of sustainability; however, some behaviours were driven by other goals than sustainability such as saving money or getting something distinctive, which can be seen as external motivations from the perspective of SDT [29]. The introjected motivations were about engaging in behaviours due to public self-consciousness or self-worth reasons, which again are not directly linked to sustainability concerns. On the other hand, some internalised motivations were linked to carrying out an activity because one has internalised values that relate to sustainability, such as animal welfare or environmental concern. Finally, intrinsic motivation was related to engaging in a behaviour because it was perceived as inherently interesting or fun, similar to how this motivation is defined in SDT, but not necessarily for the sake of sustainability. Even though taste could arguably be linked to intrinsic motivation as it relates to the hedonic experience of consuming tasty food, the interviewees seemed to perceive the taste of products as a separate incentive to sustainability to purchase sustainable foods. Taste is an important food choice motive [77], which was elicited as an external type of motivation, mainly in relation to buying food that is organic, local or in season. For externally motivated people, if such foods do not deliver on taste, they may stop buying the sustainable alternative as they do not engage in the behaviour for the sake of sustainability. Having insights into the different motivations behind sustainable behaviours in food and clothing can help inform attempts to promote such behaviours. Appealing to the internalised motivations is important as these have the potential to lead to persistent future sustainable behaviours within a domain and across domains [78], which is also in line with the role of self-identity in positive spill-over [79], even though appealing to other motives could also help [23].

Our results indicate that consumers are at different stages in the internalisation process for sustainable behaviours. According to SDT, internalisation of motives is a process that happens over time when a behaviour is adopted [29]. Even though this study did not employ a longitudinal approach, the finding that the different types of SDT motivations were elicited suggests that consumers are engaged in the internalisation process, but currently the sustainable behaviours are mainly motivated extrinsically or by introjected motivations with fewer internalised motivations. The internalisation process was apparent as each type of motivation along the self-determined continuum was elicited; however, the focus was not on placing each individual on this continuum. When interviewees gave more than one motive, the different motives were categorised as the appropriate types of motivation.

More internalised types of motivations were apparent in buying food compared to clothing. Sustainable food alternatives have been present longer on the market and people may have internalised the value of buying such products. In clothing, other behaviours across the consumption-cycle, such as using clothes for longer, were driven by more internalised motivations. Foods compared to clothes are perishable which could explain why people emphasise the use stage in clothing more and have developed various motivations to engage in such behaviours. Moreover, health was a more prevalent internalised motivation for the buying stage in food (e.g., organic food) than in clothing. This may be due to the role of these products for consumers-namely, clothes are a layer on the body whereas food is something that consumers process within the body. Based on contagion law [80], people may see contamination with potential chemicals as more of a threat with food as it is ingested.

Our study expands previous research using quantitative methods to assess the associations between the types of motivation distinguished by SDT and sustainable behaviour-e.g., [81-83] 
by providing a deeper understanding of the motives that reflect the different types of motivations. Similar to prior qualitative research in other behavioural domains that showed the relevance of applying SDT as a theoretical framework to study motivations behind sustainable behaviour in domains such as energy—e.g., [84]—or focusing on the satisfaction of the three psychological needs [61], the SDT [29] proved a useful framework in providing a way to structure the elicited motivations in food and clothing. On the other hand, some of the elicited motives were hard to categorise based on SDT (e.g., disliking shopping). Therefore, there are also some limitations to the SDT framework in helping to understand the motives behind people's sustainable behaviours.

\subsection{Implications for Future Research}

Consumers lack a good understanding of sustainability and lack of guidance regarding what constitutes sustainable options can foster amotivation. In this respect, future research is needed to investigate whether providing information in an attempt to educate consumers about sustainability can be effective or could backfire and contribute to more confusion. In the present study, we elicited top-of-mind associations that consumers have with sustainability in general and in two domains (i.e., food and clothing). To better understand how to communicate about sustainability with consumers in an effective way, future research should focus on how consumers respond to specific initiatives or campaigns about sustainability.

In relation to the elicited motivations, the extent to which these are widespread among consumers would be an interesting avenue for future research. Moreover, linking the different types of motivation with sustainable behaviours from the food and clothing domain in quantitative studies could show which ones of the motivations have the biggest potential to promote sustainable actions. Internalised motivation is most consistently linked with frequent sustainable behaviours [83] and intrinsic motivation represents the highest level of internalisation; however, the present study showed that few people are intrinsically motivated enough to engage in sustainable behaviours. Nevertheless, people were at different stages in the internalisation process of external contingencies to self; thus, longitudinal studies could try to further understand this process in order to provide insights into how to support consumers in moving through the different stages up to integrated motivation. On the other hand, if people engage in sustainable behaviour for the sake of achieving other benefits than those in line with sustainability, it becomes important to explore how the pursuit of such benefits unrelated to sustainability may affect the way people see themselves as sustainable consumers.

Several motives are important for sustainable behaviours; however, some of these may be conflicting for certain behaviours. Previous literature also shows that in the case of specific behaviours (i.e., using disposable plastic bags), consumers with a moral self-identity were less likely to engage in such a behaviour while those with a wasteful self-identity were more likely to use plastic bags [49]. It would be interesting to explore further and understand consumer choices and behaviours when different motivations or self-identities may conflict. Exploring which identities could conflict (e.g., frugal, sustainable, trendy/fashionable) for certain behaviours and how these are linked with the SDT types of motivation could shed light on consumers' motivational processes that lead to sustainable behaviours.

\subsection{Limitations}

This research is not without limitations. The research presented here used a convenience sample of young consumers gathered in a large city in Denmark. Therefore, the results cannot be generalised to represent opinions at the national level. The characteristics of young consumers might have influenced to some extent the motivational factors elicited. For example, young consumers are individuals who are either finishing their studies or are at early stages of their careers, and thus have limited financial means. This might explain why financial concerns were repeatedly mentioned in their discourses. However, their limited budgets act both as a facilitator of sustainable behaviours (i.e., avoid consumption) and as a barrier (i.e., high cost of purchasing products marketed as sustainable). Additionally, the respondents have been screened based on their interest and knowledge of sustainability and therefore, the data 
do not provide insights about consumers who are not at all interested in sustainability matters. Further research could provide such insights and investigate the reasons behind their lack of interest.

The data in this study were collected via semi-structured interviews, which presents several limitations such as problems with replicability, as they lack standardisation. To increase the transparency of the process, interviews were transcribed and NVivo was used for coding. Additionally, data coming from interviews may be affected by social desirability biases, as interviewees might feel social pressure to give socially acceptable answers-namely, answers that they feel the interviewer expects from them. In the present study, the risk of bias is considered low as participants were allowed to talk at great length about sustainability and motivations that drive their behaviours without the interviewer stopping them or sharing own opinions.

\subsection{Implications for Public Policy and Marketing}

Even though awareness of sustainability concept was high, in part also due to the selection criteria, this study shows that consumers have a fragmented overall understanding and had difficulties expressing their views on the meaning of sustainability in general as well as in food and clothing. This highlights the need for efforts to help consumers make sense of sustainability and to encourage sustainable behaviours. However, there are some differences in consumers' views about sustainability across domains-therefore, such efforts need to account for these variances. In the clothing domain, people are less knowledgeable of the economic aspects of sustainability, whereas in food they are less knowledgeable of the social and economic aspects. Some individuals refrain from engaging in sustainable behaviours due to a lack of competence regarding how to do so or simply because they are not aware of the existence of sustainable options, especially in clothing. Educating consumers on sustainability topics could facilitate more sustainable behaviours, as well as make such behaviours easier to perform. Consumers seem to be more accustomed to navigating sustainable food purchases, whereas with clothes they feel a lack of guidance. Introducing a labelling initiative to communicate sustainability overall in food and clothing could potentially support consumers in making more informed choices. Such an initiative can also give some consumers the recognition they expect when making a sustainable choice in clothing, which was highlighted as an important motivation for behaviours regarding sustainable clothing.

This research found that people buy sustainable products for various reasons, such as due to personal benefits (e.g., buy organic food due to taste benefits, buy organic food or sustainable clothes to impress others, buy suboptimal products or second-hand clothes to save money) or because such actions are in line with their values towards environmental protection and sustainability. This implies that such benefits can be used in marketing sustainable food and clothing products as well as in campaigns aiming to promote sustainable behaviours. Various motives that were not related to sustainability drove sustainable behaviours in food and clothing. This should be taken into account when attempting to promote sustainable options-namely, that emphasising the sustainability aspects is not the only way to promote choices that are sustainable. For example, positioning sustainable food as tasty or healthy could have beneficial impacts on behaviour as well. Similarly, sustainable clothes positioned as unique or long-lasting can appeal to consumers.

Consumers associate sustainability in clothing with long-lasting materials and second-hand purchases are driven by motives such as saving money or getting something unique. Thus, second-hand stores could be branded as an opportunity for consumers to acquire something unique that is still durable and not mass produced at that point in time.

\section{Conclusions}

Consumers were highly aware of sustainability, but they saw this concept as complex and difficult to interpret. When attempting to clarify what sustainability is, consumers used example of behaviours to express their views. Consumers mainly associated environmental aspects with sustainability in general and across the two domains—-food and clothing. The meanings associated with sustainability 
differed to some extent between domains-namely, social aspects and use behaviours were more closely associated with sustainability in clothing compared to food. Even though people's understanding of sustainability was fragmented, people reported engaging in sustainable behaviours along the consumption-cycle in food and clothing. People's sustainable behaviours across domains were driven by various motivations that represent the different types of motivation proposed by self-determination theory. The motivations behind sustainable behaviours varied by the stage in the consumption-cycle and domain.

Author Contributions: C.M.S., A.G. and L.L. identified the scientific problem; C.M.S. conducted the interviews and analysed the data; C.M.S., A.G. and L.L. interpreted the results; C.M.S. wrote the paper. All authors have read and agree to the published version of the manuscript.

Funding: This paper was supported by Aarhus University, Department of Management, MAPP Research Centre.

Conflicts of Interest: The authors declare no conflict of interest.

\section{Appendix A. Interview Guide}

\section{Section 1: General understanding of sustainability}

Q1. If you think about sustainability, what comes to your mind?

Q2. Do you think that sustainability is important? (wait for answer) Why is it/it isn't?

Q3. You said the sustainability is important/not important for you, is this always the case? (wait for answer) Does the context or situation in which you find yourself influence the importance of sustainability for you? (wait for answer before giving the example) e.g., if you are alone or if you are with other people (friends versus coworkers)

Q4. When a company refers to their product as sustainable, what do you think this might mean? Section 2: Sustainable behaviours

Q1. If you think about a consumer who acts in a sustainable manner, what would his/her behaviours be? Can you please give me some examples of sustainable behaviours that come to your mind (even if it is not behaviours that you engage in)?

Q2. Do you see yourself as a sustainable consumer/person?

Q3. Now if you think about your own behaviours, have you ever engaged in sustainable behaviours? Can you give me some examples? (wait for answer) Do you still engage in these behaviours?

Q4. Why do you engage in those sustainable behaviours?

Section 3: Sustainability concepts and own experiences within the apparel domain

Q1. What aspects do you consider as important when buying clothes? (What influences/shapes your clothing consumption choices?)

Q2. Is sustainability important when you choose/purchase clothes? (wait for answer) Why do you think it is/it isn't important?

Q3. What do you think that sustainability means with regards to clothing? What makes clothes sustainable? (wait for answer) If you think about the whole product life cycle, how do you see sustainability at the different stages (manufacturing/purchase, use, disposal)?

Q4. In relation to clothing, do you engage in any sustainable behaviours? Could you give me some examples?

Q5. Why do you engage in this kind of behaviours in relation to clothing? (in relation to question 4)

Q6. How easy or difficult is it to make sustainable choices in relation to clothing?

Q7. Do you see yourself as a sustainable consumer (with regards to clothing choices)?

Section 4: Sustainability concepts and own experiences within the food domain

Q1. What aspects do you consider as important when buying food? (What influences/shapes your food consumption choices?

Q2. Is sustainability important when you choose/purchase food products? (wait for answer) Why do you think it is/it isn't important? 
Q3. What do you think that sustainability means with regards to food? What makes foods sustainable? (wait for answer) If you think about the whole product life cycle, how do you see sustainability at the different stages (purchase, use, disposal)?

Q4. In relation to food, do you engage in any sustainable behaviours? Could you give me some examples?

Q5. Why do you engage in these kinds of behaviours in relation to food? (in relation to question 4)

Q6. How easy or difficult is it to make sustainable choices in relation to food?

Q7. Do you see yourself as a sustainable consumer (with regards to food choices)? 


\section{Appendix B. Consumer Associations with Sustainability and Its Associated Importance in Consumers' Minds}

\begin{tabular}{|c|c|c|c|}
\hline Description (Code) & $\begin{array}{l}\text { Number of Persons (Sustainability } \\
\text { Meaning/Importance) }\end{array}$ & Theme & Quote Example from Interviewees \\
\hline Resources (EN1) & $18 / 9$ & Environment & $\begin{array}{c}\text { "I get concerned when I see how much we dig out of the Earth, how many trees } \\
\text { were cut down, how we pollute our water, it seems like it's a never ending story } \\
\text { about just taking stuff from nature without giving anything back and never } \\
\text { replacing it with something good" }\end{array}$ \\
\hline Environment (EN2) & $5 / 3$ & Environment & $\begin{array}{c}\text { "The main thing that comes to mind with regards to sustainability is definitely the } \\
\text { environment and the planet" }\end{array}$ \\
\hline $\begin{array}{l}\text { Environment protection } \\
\qquad(\mathrm{EN} 3)\end{array}$ & $15 / 2$ & Environment & $\begin{array}{c}\text { "I am just thinking about sustainable living so sustainability (is) something } \\
\text { where you take care of the environment and your surroundings" }\end{array}$ \\
\hline Production process (EN4) & $11 / 2$ & Environment & $\begin{array}{c}\text { "avoid doing permanent damage to the soil or the water or the fish or the animal } \\
\text { population or everything there is" or "not use too many or any chemicals" }\end{array}$ \\
\hline Carbon footprint (EN5) & 3 & Environment & $\begin{array}{l}\text { "I think the first thing I think about is in terms of carbon footprint (...) and the } \\
\qquad \text { ecosystem" }\end{array}$ \\
\hline Circular economy (EN6) & 2 & Environment & $\begin{array}{c}\text { "Circular economy like the native Americans they had this nature philosophy. } \\
\text { If you take something from Earth you have to give it back, you cannot take more } \\
\text { than we actually have; (...) we have to find a way to give back, so future } \\
\text { generations can also leave from that." }\end{array}$ \\
\hline Worker wellbeing (S1) & 3 & Social & \multirow{4}{*}{$\begin{array}{l}\text { "I think when you are purchasing whatever product ... as consumer you are more } \\
\text { critical about how, or under what circumstances has this been produced and are } \\
\text { there any children working there, or what is the environment for the workers like?" }\end{array}$} \\
\hline Human rights (S2) & 2 & Social & \\
\hline Child labour (S3) & 1 & Social & \\
\hline Political (S4) & $4 / 1$ & Social & \\
\hline Economic growth (E1) & 1 & Economic & $\begin{array}{l}\text { "I have this broad understanding of sustainability. It is also about economic and } \\
\text { social sustainability, but I think it has its foundation in the environmental part so } \\
\text { if we want to create a wealthy society we have to do it from a green perspective, } \\
\text { from an environmentally-friendly perspective and the same goes for the } \\
\text { social sustainability" }\end{array}$ \\
\hline
\end{tabular}




\begin{tabular}{|c|c|c|c|}
\hline Future generations (T1) & $9 / 12$ & Temporal & \multirow{2}{*}{$\begin{array}{c}\text { "Passing on the Earth and the planet to the future generations so that they can } \\
\text { also be here and have high living standards and sustain themselves." } \\
\text { "I also think about the word long-term as opposed to short term, I think it's } \\
\text { inherited in the word (i.e., sustainability)." }\end{array}$} \\
\hline Long term/long-lasting (T2) & 5 & Temporal & \\
\hline Sceptic (P1) & 2 & Personal & \multirow{2}{*}{$\begin{array}{l}\text { "Mostly is a buzz world. It is some sort of a marketing trick most of the time. } \\
\text { Because it is so broad it can mean a lot of things and sometimes it is just used to } \\
\text { make me buy the product." } \\
\text { "I eat a lot of ecological things for example so it is, I just kind of thing that is also } \\
\text { good for the body and for that part." }\end{array}$} \\
\hline Health (P2) & $2 / 3$ & Personal & \\
\hline Efficiency (Th1) & 1 & Technology & \multirow{2}{*}{$\begin{array}{l}\text { "I think it is also related to human interacting with technology and technological } \\
\text { products. That is what I meant by long term." }\end{array}$} \\
\hline Technology (Th1) & 1 & Technology & \\
\hline Restrictive behaviours & 14 & Behaviour & $\begin{array}{l}\text { "I think about [i.e., sustainability], I always bring a tote bag, I don't use plastic } \\
\text { bags."; "think about your choices not to use too much meat, not to eat too } \\
\text { much meat." }\end{array}$ \\
\hline Purchase behaviours & 9 & Behaviour & $\begin{array}{l}\text { "I also attempt to buy a bit more organic products that are made from recyclable } \\
\text { materials"; "( . . ) something like for example ... things are produced in the right } \\
\text { way or maybe locally.";" (. . ) buying used clothes." }\end{array}$ \\
\hline $\begin{array}{l}\text { Using to prolong life of } \\
\text { products }\end{array}$ & $5 / 1$ & Behaviour & $\begin{array}{l}\text { "reuse old stuff don't throw that much out, don't buy new electronics all the } \\
\text { time.";" (... ) if I use a lot of ... you know like a plastic dish or plate and just } \\
\text { throwing it out instead of using something that I can use again." }\end{array}$ \\
\hline Disposal/Recycling & $10 / 1$ & Behaviour & $\begin{array}{c}\text { "(... ) maybe that you recycle things for example like everyday things."; "( .. ) } \\
\text { thinking about your behaviour and not just throwing stuff that can be } \\
\text { recycled away." }\end{array}$ \\
\hline Solution for current problems & 16 & - & $\begin{array}{c}\text { "if we want to continue living on this planet, we want to continue to live on this } \\
\text { planet I think it's very important to deal with environmental problems" }\end{array}$ \\
\hline Broad term & 7 & - & $\begin{array}{c}\text { "it is so broad so it is difficult to say exactly what it is"; "It could be many things, } \\
\text { it's quite a broad term" }\end{array}$ \\
\hline
\end{tabular}




\section{References}

1. Rockström, J.; Steffen, W.; Noone, K.; Persson, Å.; Chapin, F.S., III; Lambin, E.; Lenton, T.M.; Scheffer, M.; Folke, C.; Schellnhuber, H.J.; et al. Planetary Boundaries: Exploring the Safe Operating Space for Humanity. Ecol. Soc. 2009, 14. [CrossRef]

2. Vlek, C.; Steg, L. Human Behavior and Environmental Sustainability: Problems, Driving Forces, and Research Topics. J. Soc. Issues 2007, 63, 1-19. [CrossRef]

3. Koger, S.M.; Winter, D.D. The Psychology of Environmental Problems: Psychology for Sustainability; Psychology Press Taylor and Francis Group: New York, NY, USA, 2011.

4. Brundtland, G.H. Our common future-Call for action. Environ. Conserv. 1987, 14, 291-294. [CrossRef]

5. Dunlap, R.E.; Jones, R.E. Environmental concern: Conceptual and measurement issues. Handb. Environ. Sociol. 2002, 3, 482-524.

6. European Commission. Europe's Energy Transition Is Well Underway; European Commission: Brussels, Belgium, 2007.

7. United Nations. The Sustainable Development Goals Report 2017; United Nations: New York, NY, USA, 2017; Available online: https://unstats.un.org/sdgs/files/report/2017/TheSustainableDevelopmentGoalsReport2017. pdf (accessed on 6 October 2020).

8. McKinsey. Sustainability's Strategic Worth McKinsey Global Survey Results; McKinsey: New York, NY, USA, 2014.

9. Simpson, B.J.K.; Radford, S.K. Consumer Perceptions of Sustainability: A Free Elicitation Study. J. Nonprofit Public Sect. Mark. 2012, 24, 272-291. [CrossRef]

10. Hill, J.T.; Lee, H. Young Generation Y consumers' perceptions of sustainability in the apparel industry. J. Fash. Mark. Manag. Int. J. 2012, 16, 477-491. [CrossRef]

11. Kagawa, F. Dissonance in students' perceptions of sustainable development and sustainability: Implications for curriculum change. Int. J. Sustain. Higher Educ. 2007, 8, 317-338. [CrossRef]

12. Hanss, D.; Böhm, G. Sustainability seen from the perspective of consumers. Int. J. Consum. Stud. 2012, 36, 678-687. [CrossRef]

13. Lazzarini, G.A.; Visschers, V.H.M.; Siegrist, M. Our own country is best: Factors influencing consumers' sustainability perceptions of plant-based foods. Food Qual. Prefer. 2017, 60, 165-177. [CrossRef]

14. Grunert, K.G.; Hieke, S.; Wills, J. Sustainability labels on food products: Consumer motivation, understanding and use. Food Policy 2014, 44, 177-189. [CrossRef]

15. Ritch, E.L. Consumers interpreting sustainability: moving beyond food to fashion. Int. J. Retail. Distrib. Manag. 2015, 43, 1162-1181. [CrossRef]

16. Godfray, H.C.J.; Beddington, J.R.; Crute, I.R.; Haddad, L.; Lawrence, D.; Muir, J.F.; Pretty, J.; Robinson, S.; Thomas, S.M.; Toulmin, C. Food Security: The Challenge of Feeding 9 Billion People. Science 2010, 327, 812-818. [CrossRef] [PubMed]

17. Willett, W.; Rockström, J.; Loken, B.; Springmann, M.; Lang, T.; Vermeulen, S.; Garnett, T.; Tilman, D.; Declerck, F.; Wood, A.; et al. Food in the Anthropocene: the EAT-Lancet Commission on healthy diets from sustainable food systems. Lancet 2019, 393, 447-492. [CrossRef]

18. Bick, R.; Halsey, E.; Ekenga, C.C. The global environmental injustice of fast fashion. Environ. Health 2018, 17, 1-4. [CrossRef] [PubMed]

19. Ajzen, I. The theory of planned behavior. Organ. Behav. Hum. Decis. Process. 1991, 50, 179-211. [CrossRef]

20. Vermeir, I.; Verbeke, W. Sustainable food consumption: Exploring the consumer "attitude-behavioral intention" gap. J. Agric. Environ. Ethics 2006, 19, 169-194. [CrossRef]

21. Cowan, K.L.; Kinley, T.R. Green spirit: consumer empathies for green apparel. Int. J. Consum. Stud. 2014, 38, 493-499. [CrossRef]

22. Prothero, A.; Dobscha, S.; Freund, J.; Kilbourne, W.E.; Luchs, M.G.; Ozanne, L.K.; Thøgersen, J. Sustainable Consumption: Opportunities for Consumer Research and Public Policy. J. Public Policy Mark. 2011, 30, 31-38. [CrossRef]

23. Birch, D.; Memery, J.; Kanakaratne, M.D.S. The mindful consumer: Balancing egoistic and altruistic motivations to purchase local food. J. Retail. Consum. Serv. 2018, 40, 221-228. [CrossRef]

24. Ortega-Egea, J.M.; De Frutos, N.G. Toward Consumption Reduction: An Environmentally Motivated Perspective. Psychol. Mark. 2013, 30, 660-675. [CrossRef] 
25. Black, I.R.; Cherrier, H. Anti-consumption as part of living a sustainable lifestyle: daily practices, contextual motivations and subjective values. J. Consum. Behav. 2010, 9, 437-453. [CrossRef]

26. Gatersleben, B.; Murtagh, N.; Abrahamse, W. Values, identity and pro-environmental behaviour. Contemp. Soc. Sci. 2014, 9, 374-392. [CrossRef]

27. Onwezen, M.C.; Antonides, G.; Bartels, J. The Norm Activation Model: An exploration of the functions of anticipated pride and guilt in pro-environmental behaviour. J. Econ. Psychol. 2013, 39, 141-153. [CrossRef]

28. Steg, L. Values, Norms, and Intrinsic Motivation to Act Proenvironmentally. Annu. Rev. Environ. Resour. 2016, 41, 277-292. [CrossRef]

29. Deci, E.L.; Ryan, R.M. The "What" and "Why" of Goal Pursuits: Human Needs and the Self-Determination of Behavior. Psychol. Inq. 2000, 11, 227-268. [CrossRef]

30. Macnaghten, P. Public Perceptions and Sustainability in Lancashire. Indicators, Institutions, Participation. A report by the Centre for the Study of Environmental Change; Lancashire County Council: Preston, UK, 1995. [CrossRef]

31. Barone, B.; Rodrigues, H.; Nogueira, R.M.; Guimarães, K.R.L.S.L.D.Q.; Behrens, J.H. What about sustainability? Understanding consumers' conceptual representations through free word association. Int. J. Consum. Stud. 2019, 44, 44-52. [CrossRef]

32. Paloviita, A. Consumers' Sustainability Perceptions of the Supply Chain of Locally Produced Food. Sustainability 2010, 2, 1492-1509. [CrossRef]

33. Peano, C.; Merlino, V.M.; Sottile, F.; Borra, D.; Massaglia, S. Sustainability for Food Consumers: Which Perception? Sustainability 2019, 11, 5955. [CrossRef]

34. Gam, H.J.; Banning, J. Addressing Sustainable Apparel Design Challenges With Problem-Based Learning. Cloth. Text. Res. J. 2011, 29, 202-215. [CrossRef]

35. Prada, M.; Garrido, M.V.; Rodrigues, D.L. Lost in processing? Perceived healthfulness, taste and caloric content of whole and processed organic food. Appetite 2017, 114, 175-186. [CrossRef]

36. Bernard, J.C.; Liu, Y. Are beliefs stronger than taste? A field experiment on organic and local apples. Food Qual. Preference 2017, 61, 55-62. [CrossRef]

37. Sörqvist, P.; Haga, A.; Langeborg, L.; Holmgren, M.; Wallinder, M.; Nöstl, A.; Seager, P.B.; Marsh, J.E. The green halo: Mechanisms and limits of the eco-label effect. Food Qual. Prefer. 2015, 43, 1-9. [CrossRef]

38. Bratanova, B.; Vauclair, C.-M.; Kervyn, N.; Schumann, S.; Wood, R.; Klein, O. Savouring morality. Moral satisfaction renders food of ethical origin subjectively tastier. Appetite 2015, 91, 137-149. [CrossRef] [PubMed]

39. Meyerding, S.G.; Schaffmann, A.-L.; Lehberger, M. Consumer Preferences for Different Designs of Carbon Footprint Labelling on Tomatoes in Germany_Does Design Matter? Sustainability 2019, 11, 1587. [CrossRef]

40. Dickson, M.A. Utility of No Sweat Labels for Apparel Consumers: Profiling Label Users and Predicting Their Purchases. J. Consum. Aff. 2001, 35, 96-119. [CrossRef]

41. Rothenberg, L.; Matthews, D. Consumer decision making when purchasing eco-friendly apparel. Int. J. Retail. Distrib. Manag. 2017, 45, 404-418. [CrossRef]

42. Kostadinova, E. Sustainable consumer behavior: Literature overview. Econ. Altern. 2016, 2, 224-234.

43. Steg, L.; Vlek, C. Encouraging pro-environmental behaviour: An integrative review and research agenda. J. Environ. Psychol. 2009, 29, 309-317. [CrossRef]

44. Asioli, D.; Aschemann-Witzel, J. Sustainability-Related Food Labels. Annu. Rev. Resour. Econ. 2020, 12, 171-185. [CrossRef]

45. Oyserman, D. Identity-based motivation: Implications for action-readiness, procedural-readiness, and consumer behavior. J. Consum. Psychol. 2009, 19, 250-260. [CrossRef]

46. Solomon, M.R.; Bamossy, G.; Askegaard, S. Consumer Behavior; PrenticeHall, Inc.: Upper Saddle River, NJ, USA, 1999.

47. Schwartz, S.H. Normative Influences on Altruism. Adv. Exp. Soc. Psychol. 1977, 10, 221-279. [CrossRef]

48. De Groot, J.I.; Steg, L. Value orientations to explain beliefs related to environmental significant behavior: How to measure egoistic, altruistic, and biospheric value orientations. Environ. Behav. 2008, 40, 330-354. [CrossRef]

49. Gatersleben, B.; Murtagh, N.; Cherry, M.; Watkins, M. Moral, Wasteful, Frugal, or Thrifty? Identifying Consumer Identities to Understand and Manage Pro-Environmental Behavior. Environ. Behav. 2017, 51, $24-49$. [CrossRef] 
50. Ryan, R.M.; Deci, E.L. Intrinsic and Extrinsic Motivations: Classic Definitions and New Directions. Contemp. Educ. Psychol. 2000, 25, 54-67. [CrossRef]

51. Pelletier, L.G.; Tuson, K.M.; Green-Demers, I.; Noels, K.; Beaton, A.M. Why Are You Doing Things for the Environment? The Motivation Toward the Environment Scale (MTES)1. J. Appl. Soc. Psychol. 1998, 28, 437-468. [CrossRef]

52. Villacorta, M.; Koestner, R.; Lekes, N. Further Validation of the Motivation Toward the Environment Scale. Environ. Behav. 2003, 35, 486-505. [CrossRef]

53. Pelletier, L.G. 10: A Motivational Analysis of Self-Determination for Pro-Environmental Behaviors. In Handbook of Self-Determination Research; Press Rochester: Rochester, NY, USA, 2002; pp. 205-232.

54. Longhurst, R. Semi-structured interviews and focus groups. Key Methods Geogr. 2003, 3, 143-156.

55. Bucic, T.; Harris, J.; Arli, D.I. Ethical Consumers among the Millennials: A Cross-National Study. J. Bus. Ethic 2012, 110, 113-131. [CrossRef]

56. Kanchanapibul, M.; Lacka, E.; Wang, X.; Chan, H.K. An empirical investigation of green purchase behaviour among the young generation. J. Clean. Prod. 2014, 66, 528-536. [CrossRef]

57. Naderi, I.; Van Steenburg, E. Me first, then the environment: young Millennials as green consumers. Young Consum. 2018, 19, 280-295. [CrossRef]

58. Diamantopoulos, A.; Schlegelmilch, B.B.; Sinkovics, R.R.; Bohlen, G.M. Can socio-demographics still play a role in profiling green consumers? A review of the evidence and an empirical investigation. J. Bus. Res. 2003, 56, 465-480. [CrossRef]

59. Saunders, M.; Townsend, K. Reporting and Justifying the Number of Interview Participants in Organization and Workplace Research. Br. J. Manag. 2016, 27, 836-852. [CrossRef]

60. Shenton, A.K. Strategies for ensuring trustworthiness in qualitative research projects. Educ. Inf. 2004, 22, 63-75. [CrossRef]

61. Abdulrazak, S.; Quoquab, F. Exploring Consumers' Motivations for Sustainable Consumption: A Self-Deterministic Approach. J. Int. Consum. Mark. 2017, 30, 14-28. [CrossRef]

62. Carrete, L.; Castaño, R.; Felix, R.; Centeno, E.; González, E. Green consumer behavior in an emerging economy: confusion, credibility, and compatibility. J. Consum. Mark. 2012, 29, 470-481. [CrossRef]

63. Moisander, J.; Pesonen, S. Narratives of sustainable ways of living: constructing the self and the other as a green consumer. Manag. Decis. 2002, 40, 329-342. [CrossRef]

64. Graebner, M.E.; Martin, J.A.; Roundy, P.T. Qualitative data: Cooking without a recipe. Strat. Organ. 2012, 10, 276-284. [CrossRef]

65. Saldaña, J. The Coding Manual for Qualitative Researchers; SAGE: London, UK, 2015.

66. Ryan, R.M.; Williams, G.C.; Patrick, H.; Deci, E.L. Self-determination theory and physical activity: The dynamics of motivation in development and wellness. Hellenic Journal of Psychology. 2009, 6, 107-124.

67. Catlin, J.R.; Luchs, M.G.; Phipps, M. Consumer Perceptions of the Social Vs. Environmental Dimensions of Sustainability. J. Consum. Policy 2017, 40, 245-277. [CrossRef]

68. Gwozdz, W.; Netter, S.; Bjartmarz, T.; Reisch, L.A. Survey Results on Fashion Consumption and Sustainability among Young Swedes; Report Mistra Future Fashion; Mistra Future Fashion: Borås, Sweden, 2013.

69. Manik, J.A.; Greenhouse, S.; Yardley, J. Western Firms Feel Pressure As Toll Rises in Bangladesh. New York Times. 25 April 2013. Available online: http:/www.nytimes.com/2013/04/26/world/asia/bangladeshi-collapse-killsmany-garment-workers.html?smid=pl-share (accessed on 10 September 2020).

70. Ritch, E.L. Extending sustainability from food to fashion consumption: the lived experience of working mothers. Int. J. Manag. Cases 2014, 16, 17-31.

71. Peattie, K.; Collins, A. Guest editorial: perspectives on sustainable consumption. Int. J. Consum. Stud. 2009, 33, 107-112. [CrossRef]

72. Dickenbrok, C.; Martinez, L.F. Communicating green fashion across different cultures and geographical regions. Int. Rev. Public Nonprofit Mark. 2018, 15, 127-141. [CrossRef]

73. McNeill, L.; Moore, R. Sustainable fashion consumption and the fast fashion conundrum: fashionable consumers and attitudes to sustainability in clothing choice. Int. J. Consum. Stud. 2015, 39, $212-222$. [CrossRef]

74. Rana, J.; Paul, J. Health motive and the purchase of organic food: A meta-analytic review. Int. J. Consum. Stud. 2020, 44, 162-171. [CrossRef] 
75. Beard, N.D. The Branding of Ethical Fashion and the Consumer: A Luxury Niche or Mass-market Reality? Fash. Theory 2008, 12, 447-467. [CrossRef]

76. Eurostat. Half of Spending on Housing, Transport and Food. 2019. Available online: https://ec.europa.eu/ eurostat/web/products-eurostat-news/-/WDN-20190703-1 (accessed on 10 September 2020).

77. Steptoe, A.; Pollard, T.M.; Wardle, J. Development of a Measure of the Motives Underlying the Selection of Food: the Food Choice Questionnaire. Appetite 1995, 25, 267-284. [CrossRef]

78. Aitken, N.M.; Pelletier, L.G.; Baxter, D.E. Doing the Difficult Stuff: Influence of Self-Determined Motivation Toward the Environment on Transportation Proenvironmental Behavior. Ecopsychology 2016, 8, 153-162. [CrossRef]

79. Van Der Werff, E.; Steg, L.; Keizer, K. Follow the signal: When past pro-environmental actions signal who you are. J. Environ. Psychol. 2014, 40, 273-282. [CrossRef]

80. Nemeroff, C.; Rozin, P. The Contagion Concept in Adult Thinking in the United States: Transmission of Germs and of Interpersonal Influence. Ethos 1994, 22, 158-186. [CrossRef]

81. Grønhøj, A.; Thøgersen, J. Why young people do things for the environment: The role of parenting for adolescents' motivation to engage in pro-environmental behaviour. J. Environ. Psychol. 2017, 54, 11-19. [CrossRef]

82. Sass, W.; Pauw, J.; Donche, V.; Petegem, P. “Why (Should) I Do Something for the Environment?” Profiles of Flemish Adolescents' Motivation Toward the Environment. Sustainability 2018, 10, 2579. [CrossRef]

83. Green-Demers, I.; Pelletier, L.G.; Ménard, S. The impact of behavioural difficulty on the saliency of the association between self-determined motivation and environmental behaviours. Can. J. Behav. Sci. Rev. Can. Sci. Comport. 1997, 29, 157-166. [CrossRef]

84. Shin, H.D.; Bhamra, T. Design for sustainable behaviour: a case study of using human-power as an everyday energy source. J. Design Res. 2016, 14, 280-299. [CrossRef]

Publisher's Note: MDPI stays neutral with regard to jurisdictional claims in published maps and institutional affiliations.

(C) 2020 by the authors. Licensee MDPI, Basel, Switzerland. This article is an open access article distributed under the terms and conditions of the Creative Commons Attribution (CC BY) license (http://creativecommons.org/licenses/by/4.0/). 